\title{
The Georgian prostitutes: exotic and erotic
}

\section{Lesley Smith}

\section{Society prostitution}

Logic, science and a whole new range of philosophies arrived in Great Britain alongside George I who ascended the throne in 1714. There were more than 50 Catholics who had a greater right to the throne than George, but Britain would not tolerate another Catholic - however close to the throne. The non-English-speaking German was less interested in intellectuals than in gunpowder, cannons and his two mistresses, one of whom was tall and the other as round as a barrel. This new king was hugely entertaining to the general public, it seems, and somewhat alarming to the English Court. However, the libertine behaviour of many courtiers was widely known. In fact, Georgian society was probably when prostitution was at its most prolific. This is a period when courtesans could become duchesses and some did. Amy Lyon - who later became Emma Hart, a "posture moll" - would strip for an audience and then pose as required or allow herself to be whipped. Well documented are the wild dinners for men with drinking, gambling and, according to one account, balancing wine glasses on the mons veneris (mound of Venus) of a "posture moll". Apparently this lewd public behaviour didn't put off suitors, as Emma Hart later would become Nelson's Lady Hamilton.

\section{Sex and art}

A great deal of published evidence of sexual activity in the 18 th century can be found in books, songs, poems and a large number of sketches and engravings, the most famous of all being the work of William Hogarth (1697-1764). Another artist, William Humphrey (1740-c.1810), depicts prostitution in his work, The Whore's Last Shift, in 1779. Flagellation seems to be very popular, particularly enjoyed by the Bishop of Bath and Wells. Whipping frames had red ribbons for the army and blue for the navy. History doesn't tell us the colour of the clergy ribbons.

In portrait paintings one can see the idealised beauty of the day. Not rather pug-like as in Charles II's time, but instead the Hapsburg chin can be observed in portraits hanging in many an art gallery and stately home. The perfect mistress or wife would be petite, doe-eyed and childlike. Emma Hamilton is a classic example of this style. Conversely, there were also the exaggerated court displays of the great grey powdered wigs, painted cheeks and lips. Men were, it seems, either high painted, bewigged and foppish or hero types, with large numbers of the latter joining the uniformed forces to cut a dash as heroes on ships or horseback.

\section{Thriving sex industry}

When George I arrived in England, Drury Lane in London was already the centre of the fashionable sex industry, with clients largely drawn from the richer echelons of society. A century before, Oliver Cromwell had closed the theatres, as he believed them to be a focus of sinful behaviour - he was right - as many actresses also had a sideline in prostitution, with some theatres having brothels actually attached to the back of the building.

J Fam Plann Reprod Health Care 2010; 36(3): 177-178

Tutbury Castle, Tutbury, UK

Lesley Smith, Curator

Correspondence to: Lesley Smith, Tutbury Castle, Tutbury, Staffordshire DE13 9JF, UK. E-mail: info@tutburycastle.com
Many of the most notorious sex industry figures were recorded, such as John Heidegger (of Swiss descent) and his lover, Mrs Whyburn, who put on a series of "masquerades" featuring "playlets" of "gaiety and lewdness". These pornographic stage performances stimulated their audiences to the second stage of the market sale, which was the large group of prostitutes run by Mrs Whyburn.

Mrs Whyburn was an extraordinary woman; she was highly manipulative and even had royal contacts to protect her interests. She was hideously ugly in later life and was commonly seen carrying holy books as she toured around the ale houses and carriage stops to try to 'buy' the young women, often children, who had just arrived in London. It seems she often succeeded in taking these naive souls to her whorehouses with promises of a better, wholesome life. These desperate youngsters were trying to escape the poverty of the countryside only to find themselves in the vice-like grip of procuresses such a Mrs Whyburn and another notorious woman, the well-documented Mother Needham.

These young girls were desirable not only because of their youth and beauty but also because there was a good chance they would be virgins, fetching a vast price for deflowering, and also because they would be free of the French pox. Not for long it seems, however, for syphilis by now was rife in society, condoms described as "condums" were brought in large numbers into the brothels, but it seems that venereal diseases were carried into the throat and mouth and great disfigurement occurred as a result. Leather masks were worn by those too greatly disfigured to be tolerated in general society. These poor creatures would be cast out to fend for themselves, as would most other prostitutes when they reached the ripe old age of 30 years, and they could sometimes be found working as what was known as "twopenny bunters", offering their bodies in the dark and often under bridges.

Many of the brothel keepers became rich and famous, competing to provide the most luxurious establishments. Some were, however, occasionally in trouble with the law, eventually even Mrs Needham and her army of "great impures", who had started to cause a scandal; despite her elevated contacts she became known as "the She-Captain of Satan". Mrs Needham died in 1720, early in the Georgian period, and despite enquiries had somehow avoided prosecution. Her "masquerades" had become so pornographic that laws were passed by George I to close them in 1721 .

\section{Medical remedies}

Mercury, known at that time as "quicksilver", was still the only form of treatment for syphilis and it was used in a number of ways both topically and taken orally.

Abortion, both surgical and from the ingestion of poisonous compounds, was a common occurrence, and again we see Hogarth prints depicting drunken women in the London slums with their babies falling unheeded from laps, reminding us of the tragic life in the gutter, literally.

Medicine enjoyed a complete revolution in analysis, methodology and exchange of intellectual views at what we would now call conferences. There were conflicts of opinion, of course, and out of these conflicts and debates many lasting principles of science were founded. 


\section{Future articles}

The next article in this series will be on "Alexander Gordon: Women's Doctor of Aberdeen".

\section{Acknowledgement}

The author would like to thank Dr G Williams, British Museum, London, UK for his help and advice.

\section{Sources}

1 A Harlot's Progress (also known as The Harlot's Progress) is a series of six paintings (1731, now lost) and engravings (1732) by William Hogarth. The series shows the story of a young woman, Mary (or Moll) Hackabout, who arrives in London from the country and becomes a prostitute. http://en.wikipedia.org/ wiki/A_Harlot\%27s_Progress [Accessed 10 February 2010].

2 http://www.artcyclopedia.com/artists/hogarth_william.html. [Accessed 10 February 2010].

3 The British Museum has a fantastic range of prints and paintings from the Georgian period that can also be viewed on their website (www.britishmuseum.org).

\section{Bibliography}

1 Stone, Lawrence. The Family, Sex and Marriage in England 1500-1800. First published by Weidenfeld \& Nicolson, 1977. Abridged and revised edition published by Pelican Books, 1979.
2 Herman, Eleanor. Sex with Kings. London, UK: Harper Collins, 2004.

3 Tannahill, Reay. Sex in History. London, UK: Abacus, 1989.

4 Burford, EJ and Wotton, Joy. Private Vices - Public Virtues. London, UK: Robert Hale, 1995.

5 Pepys, Samuel. The Dairies of Samuel Pepys. Published and edited by RG Howarth, Penguin Books, 1933.

6 Hatton, R. George I (Yale English Monarchs Series). New Haven, CT: Yale University Press, 2001.

7 Porter, Ian A. Alexander Gordon 1752-1799. Edinburgh, UK: Oliver \& Boyd, 1958.

8 Abrams, Rebecca. Touching Distance. London, UK: Macmillan, 2008.

\section{About the author}

Lesley Smith is currently a postgraduate student in the Centre for the History of Medicine of the University of Birmingham, where she is developing a $\mathrm{PhD}$ in obstetrics and gynaecology in early modern Britain. She holds an honorary degree for "services to history". She makes 200-300 public appearances a year and also works as a TV historian in the UK and abroad including the USA. Lesley is also Curator of Tutbury Castle in Staffordshire and is a member of the Society of Apothecaries of London and the Society of Medical Writers.

\section{NEWS ROUNDUP}

Phase 1 testing for herpes vaccine A herpes vaccine has begun phase one testing at Chelsea and Westminster Hospital in London. Two healthy volunteers have been given the vaccine, in a safety trial which will involve 42 people. Simon Barton, a consultant in genitourinary medicine at Chelsea and Westminster Hospital, who is running the study, said that a genital herpes vaccine would have important benefits. "For many of the people with genital herpes I look after, the big issue is having a way of protecting their partners", Dr Barton said. "They can reduce the risk of transmission by using condoms and taking antiviral drugs every day, but these are far from ideal and they do not reduce the risk to zero"

BioVex, a biotechnology company, has designed the ImmunoVex HSV2 vaccine based on a live but weakened version of HSV2, which has been engineered to silence four genes that help the virus to hide from the immune system. This should allow it to generate an immune response capable of preventing infection. The initial Phase 1 trial will evaluate whether the virus is safe in healthy volunteers, and whether it generates a good immune response. If the results are positive, it will go on to be tested for efficacy on the partners of people with herpes. Source: http://www.timesonline.co.uk/tol/news/uk/health/article

\section{Sexual Health in Holland in the Spring}

May 2010 saw the 11th Biennial Congress of the European Society of Contraception (ESC) held in The Hague, The Netherlands. Over 2000 clinicians from all over Europe and beyond, including 80 or so from the UK, came together for 3 days. Highlights included sunshine; trips to the bohemian delights of Scheveningen beach once trams were mastered; meeting colleagues that we only see every other year; catching up with old friends; as well as attending some interesting and informative sessions at the light and airy congress building. One session that struck a chord with many delegates was about women requesting hymen reconstruction for fear of repercussions from future spouses and families. This was particularly emotional and moving. There were a number of contributions by UK delegates including Dr Audrey Brown and her colleagues who won a prize for a free communication.

A minor, but nevertheless significant, event took place late on Friday afternoon at The General Assembly, namely the voting of representatives onto the ESC Board. Member countries are allowed one or two representatives depending on the number of ESC members they have. On this occasion Sarah Randall was stepping down as one of the two UK representatives (and as Secretary General) and Shelley Mehigan was elected as the second UK representative - the first non-doctor to be elected to the ESC Board. [NB. Shelley also serves as Nurse Representative on the Journal of Family Planning and Reproductive Health Care.]

\section{Drug resistance in gonorrhoea}

At the Society for General Microbiology's Spring meeting in Edinburgh, Professor Catherine Ison from the Health Protection Agency (HPA) reported growing resistance to antibiotics in gonorrhoea. Current drugs are still effective but signs of emerging resistance mean treatments may soon need to be revised with combinations of drugs. The HPA has been keeping a close watch on antibiotic resistance among strains of gonorrhoea for some time and says there is an urgent need for the development of new treatments. If left untreated, gonorrhoea can lead to pelvic inflammatory disease, and women can become infertile or have ectopic pregnancies. The current treatment to use is either ceftriaxone or cefixime. These antibiotics are administered as a single dose.

Professor Ison said: "Choosing an effective antibiotic can be a challenge because the organism that causes gonorrhoea is very versatile and develops resistance to antibiotics very quickly. Penicillin was used for many years until it was no longer effective and a number of other agents have been used since. The current drugs of choice, ceftriaxone and cefixime, are still very effective but there are signs that resistance, particularly to cefixime, is emerging and soon these drugs may not be a good choice. If this problem isn't addressed then there is a real possibility that gonorrhoea will become a very difficult infection to treat." The risk is that if several doses of treatment are required and patients do not finish the course, multi-resistant strains may emerge.

The HPA says there is no need to change treatment at the moment, but it is important for doctors to be vigilant. It says the high number of cases of sexually transmitted infections (STIs) such as gonorrhoea reinforces the need for people to use condoms with new and casual partners. Jason Warriner, Clinical Director at the Terrence Higgins Trust, said: "As levels of STIs continue to rise, we will see drug-resistant strains develop. This just shows how crucial it is for those who have been at risk to go for regular sexual health check-ups. We recommend people who are sexually active get checked out at least once a year. Most modern tests involve a simple urine sample or self-administered swab. They are quick, easy, and a good way to achieve peace of mind.'

Source: http://news.bbc.co.uk///hi/health/8593366.stm

Reviewed by Henrietta Hughes, MRCGP, DFSRH General Practitioner, London, UK

\section{READERS' CONTRIBUTIONS INVITED ON 'A BETTER WAY OF WORKING'}

The Journal publishes occcasional 'A Better Way of Working' articles, the purpose of which is to disseminate service delivery suggestions likely to be of interest and relevance to the Journal's readership. Readers are invited to submit suggestions based on their own personal experience for consideration by the Journal Editor. Contributions normally should not exceed 1000 words and should be written in a standardised format responding to the following four questions (or similar): Why was change needed? How did you go about implementing change? What advice would you give to others who might be considering a similar course of action? How did you show that the change had occurred? All contributions should be submitted via the Journal's online submission system at http://jfprhc.allentrack.net. 